\title{
Convergent evolution of highly reduced fruiting bodies in Pezizomycotina suggests key adaptations to the bee habitat
}

Anja Amtoft Wynns

\begin{abstract}
Background: Among the understudied fungi found in nature are those living in close association with social and solitary bees. The bee-specialist genera Bettsia, Ascosphaera and Eremascus are remarkable not only for their specialized niche but also for their simple fruiting bodies or ascocarps, which are morphologically anomalous in Pezizomycotina. Bettsia and Ascosphaera are characterized by a unicellular cyst-like cleistothecium known as a spore cyst, while Eremascus is characterized by completely naked asci, or asci not formed within a protective ascocarp. Before molecular phylogenetics the placement of these genera within Pezizomycotina remained tentative; morphological characters were misleading because they do not produce multicellular ascocarps, a defining character of Pezizomycotina. Because of their unique fruiting bodies, the close relationship of these bee-specialist fungi and their monophyly appeared certain. However, recent molecular studies have shown that Bettsia is not closely related to Ascosphaera.

In this study, I isolated the very rare fungus Eremascus fertilis (Ascomycota, Pezizomycotina) from the bee bread of honey bees. These isolates represent the second report of $E$. fertilis both in nature and in the honey bee hive. To establish the systematic position of E. fertilis and Bettsia alvei, I performed phylogenetic analyses of nuclear ribosomal LSU + SSU DNA sequences from these species and 63 additional ascomycetes.

Results: The phylogenetic analyses revealed that Eremascus is not monophyletic. Eremascus albus is closely related to Ascosphaera in Eurotiomycetes while E. fertilis belongs in Myxotrichaceae, a putative member of Leotiomycetes. Bettsia is not closely related to Ascosphaera and like E. fertilis apparently belongs in Leotiomycetes. These results indicate that both the naked ascus and spore cyst evolved twice in the Pezizomycotina and in distantly related lineages. The new genus Skoua is described to accommodate E. fertilis.

Conclusions: The naked ascus and spore cyst are both shown to have evolved convergently within the bee habitat. The convergent evolution of these unusual ascocarps is hypothesized to be adaptive for bee-mediated dispersal. Elucidating the dispersal strategies of these fungal symbionts contributes to our understanding of their interaction with bees and provides insight into the factors which potentially drive the evolution of reduced ascocarps in Pezizomycotina.
\end{abstract}

Keywords: Ascosphaerales, Eremascaceae, Honey bees, Solitary bees, Yeasts, Skoua

\section{Background}

The Ascomycota are an ecologically diverse group of fungi characterized by the production of meiospores in sac-like structures called asci. In the subphylum Pezizomycotina, asci are formed within a protective ascocarp, while in the basal lineages (Saccharomycotina and nearly all members of Taphrinomycotina) asci lack a protective

Correspondence: aaw@plen.ku.dk

Center for Social Evolution and Department of Plant and Environmental Sciences, University of Copenhagen, Thorvaldsensvej 40, Frederiksberg C 1871, Denmark

\section{Biomed Central}

covering and are called naked asci. Four major multicellular ascocarp types are recognized in the Ascomycota: apothecia (cup-shaped ascocarps with an exposed hymenium), perithecia (flask-shaped ascocarps with a pore through which ascospores are released), pseudothecia (ascocarps with asci contained in numerous locules), and cleistothecia (entirely closed ascocarps with no predefined opening and no regular arrangement of asci) $[1,2]$. The traditional classification system of Pezizomycotina (Ascomycota) placed great emphasis on these ascocarp types. Subsequently, DNA sequence-based phylogenies have 
shown that similar ascocarp types have evolved multiple times in distantly related lineages [3, 4]. As more sequence data become available, it is increasingly clear that morphological convergence of ascocarp types is not uncommon, and that the evolution of ascocarps and modes of ascus and ascocarp dehiscence are frequently associated with common spore dispersal strategies $[5,6,4]$.

Phylogenetic studies have identified the major lineages shaping the backbone of the fungal tree of life $[7,8,4]$ but the placement of many taxa at and below the class level remains uncertain. Increased DNA sampling of understudied groups, especially those whose systematic placement is based on morphology, may be critical for enabling ancestral-state reconstructions of characteristics such as ascus-dehiscence type, ascocarp ontogeny, and lifestyle and spore dispersal strategies.

The three bee-specialist genera Ascosphaera, Arrhenosphaera (Ascosphaeraceae; Eurotiomycetes) and Bettsia (incertae cedis; formerly Ascosphaeraceae) are among the understudied and seldom-collected fungi. Within the bee habitat these fungi lead both saprotrophic and pathogenic lifestyles. They are found growing on pollen provisions, larval feces (Fig. 1e-f), cocoons, materials used by the bees to construct brood cells, and within bee larvae [9-15]. At least half of the species of Ascosphaera are bee brood pathogens infecting the larval stage and causing the bee disease commonly known as chalkbrood. In addition to sharing a specialized ecological niche [16], Ascosphaera, Arrhenosphaera and Bettsia are remarkable for their ascocarps (Figs. 1-2) which are morphologically anomalous in Pezizomycotina. Before DNA sequence data were available, the placement of Ascosphaeraceae among the Fungi and later within the Ascomycota was much debated [17-20]. Their odd ascocarps, called spore cysts, led some to suggest that members of Ascosphaeraceae might not be fungi at all or were possibly more closely related to genera in Entomophthoromycota (an early diverging lineage of Fungi) than to Ascomycota [18]. Spore cysts are completely closed ascocarps, which macroscopically resemble the multicellular cleistothecia of other fungi. However, the ontogeny and structure of a spore cyst and a cleistothecium differ. In a cleistothecium the asci develop within a multicellular ascocarp with variable complexity of the peridium, or ascocarp wall. In a spore cyst, evanescent asci develop within a single, enlarged cell which forms a cystlike ascocarp with a simple acellular membranous peridium $[17,20]$.

Recent phylogenetic studies [21, 22] suggest that spore cysts have evolved at least twice and that Bettsia is more closely related to the class Leotiomycetes than to Ascosphaeraceae (Eurotiomycetes). Earlier phylogenetic studies supported a monophyletic Ascosphaeraceae; however, these studies included just two representatives of the family - Ascosphaera apis (Claussen) L.S. Olive \& Spiltoir and A. atra Skou \& K. Hackett (as A. apis in Berbee et al. 1995) - and not Bettsia [23, 24]. Because of the striking similarity of the ascocarps in Bettsia and Ascosphaera, and their shared predilection for the bee habitat, the position of B. alvei (Betts) Skou in the Leotiomycetes and the polyphyly of Ascosphaeraceae were formerly unsuspected. The affinity of the monotypic genus Arrhenosphaera to Ascosphaeraceae is based on the shared character of a spore cyst. Unfortunately, no holotype was designated in the protologue of Arrhenosphaera cranei Stejskal [9] and no additional collections or reports of the fungus have been made since its description as a problematic pathogen of honey bees in Venezuela in 1974.

The placement of Ascosphaeraceae in Eurotiales (Eurotiomycetidae) is based on similar early sexual development in Monascus and Aspergillus [17, 25], and is supported by DNA sequence-based phylogenies [3, 24]. These phylogenies also revealed a close relationship between Ascosphaeraceae and Eremascaceae, a family of just one genus, Eremascus. Ascosphaeraceae and Eremascus both lack hyphal fruiting bodies and for this reason were loosely referred to as 'yeasts' [26]. The shared simple ascocarp morphology of these two taxa was recognized before molecular data became available but their possible relatedness was doubted because of differences in their sexual systems [25, 27].

The genus Eremascus includes two species, E. fertilis Stoppel and E. albus Eidam, and is characterized by naked asci and a predilection for high sugar substrates [28]. Naked asci, with no interspersed sterile hyphae, occur elsewhere only within the early diverging lineages of the Ascomycota: the yeast-like Taphrinomycotina and the true-yeasts, Saccharomycotina [29]. The morphological similarity of Eremascus to the yeast-like fungi led some authors to believe that Eremascus should be placed among the Saccharomycetales, noting that the genus differs from other members of this group only in lacking asexual reproduction by budding or otherwise [30, 19]. Despite its unique fruiting body type within the Pezizomycotina, Eremascus has received little attention in phylogenetic studies. The prevailing view has been that Eremascus is monophyletic [31,28], and its closest relative is Ascosphaeraceae [24, 32, 26]. The supposed monophyly of the genus is based on the shared character of completely naked asci, while the two species (E. fertilis and $E$. albus) differ in ascospore morphology and sexual development $[27,33]$.

Both Eremascus species are xerophiles thriving in conditions where water activity is low and solute concentrations are high [28]. The natural habitat of Eremascus remains elusive; both species are very rarely collected and have previously been isolated only from various 


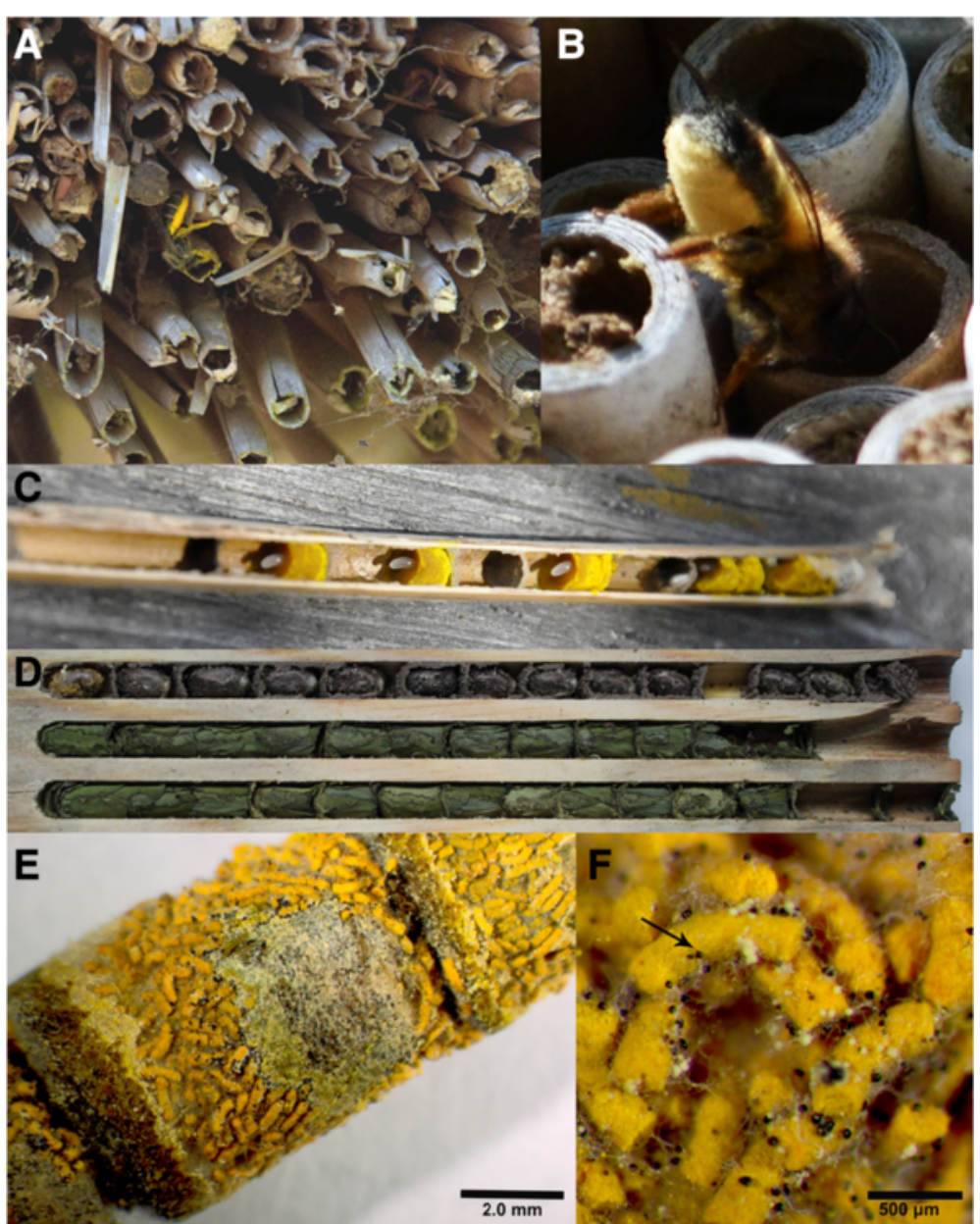

Fig. 1 a. The solitary bee Chelostoma florisomne entering its nest - a Phragmites reed of a thatched roof. b. The solitary bee Osmia bicornis entering a commercial solitary bee nest made of cardboard tubes. c. A Phragmites reed peeled open to reveal the linear arrangement of brood cells built by C. florisomne, each containing pollen provisions and an egg. $\mathbf{d}$. Opened man-made nest showing cocoons of Osmia bicornis (top row) and the leafcutting bee Megachile centucularis (bottom two rows). e. brood cell of Osmia leaiana containing a coccon and larval fecal pellets (orange cylinders) with Ascosphaera sporecysts. f. Close-up of larval fecal pellets from Fig. 1e and intact spore cysts (arrow). Scale bars: $\mathrm{E}=20 \mathrm{~mm}, \mathrm{~F}=500 \mu \mathrm{m}$

high-sugar foods such as prunes, preserved fruit, shortcake, plum jam, mincemeat, honeycomb and on pollen $[28,34,35]$. In the process of studying the diversity of spore cyst fungi in the nests of solitary bees and in the hives of honey bees in Denmark, Eremascus fertilis was serendipitously isolated from the beebread of honey bee hives. This is the second report of E. fertilis in nature: the first report was in 1912 when A. Betts also observed the fungus growing on pollen in honey bee hives [35].

Eremascus fertilis has not previously been included in phylogenetic studies at the class level. In this study, I sequenced the large subunit (LSU) and small subunit (SSU) nuclear ribosomal DNA regions for E. fertilis and also for Bettsia alvei. These sequences were added to a large matrix of sequences from other Ascomycota, which was then analyzed both by maximum parsimony and
Bayesian inference. Based on the resulting phylogenies, a theory for the adaptive significance of the spore cyst and naked ascus within the bee habitat is proposed.

\section{Methods}

\section{Morphological study}

Spore cysts and asci were mounted in water on glass slides. Light photomicrographs were made on an Olympus AX70 Provis light microscope. Herbarium acronyms follow those of Index Herbariorum [36] .

\section{Collection}

Ninety-six solitary bee nests were placed at eight localities on the island of Sjælland, Denmark. The nest holes ranged from 6 to $9 \mathrm{~mm}$ in diameter (to attract different species of cavity-nesting bees) and had a length of $19.5 \mathrm{~cm}$. 


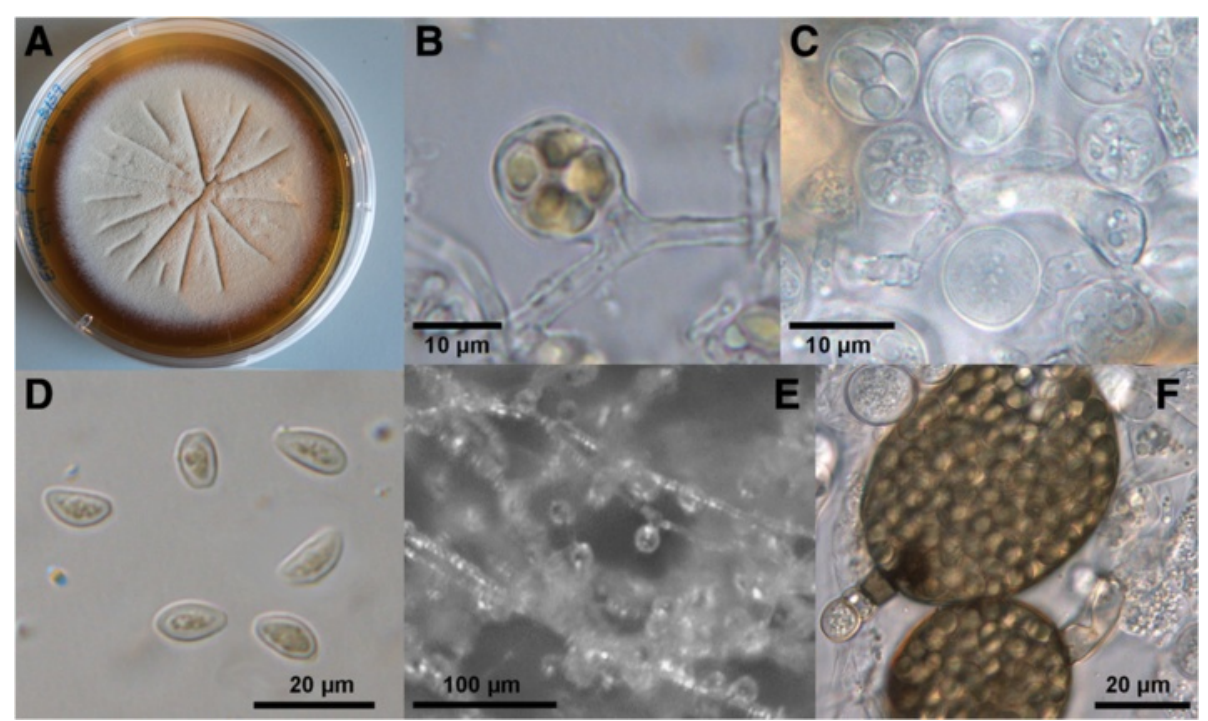

Fig. 2 a-e: Skoua fertilis. A. Culture on MY20. b-c. Naked asci. d. Ascospores and pollen grains (orange). e. Hyphae bearing naked asci. f. Spore cysts of Bettsia alvei containing spherical ascospores. Scale bars: $B-C=10 \mu \mathrm{m}, \mathrm{D}=20 \mu \mathrm{m}, \mathrm{E}=100 \mu \mathrm{m}, \mathrm{F}=20 \mu \mathrm{m}$

The nests were placed 1-2.5 meters above the ground on the sides of buildings or below eaves with the entrances positioned to face southeast. Nests were opened and inspected annually from 2008 to 2012. Fungi growing on the pollen provisions, larvae, cocoons and nesting material were removed from a subset of the nests and identified. Overwintered honey bee (Apis mellifera) frames containing bee bread were collected in 2010 from three managed hives in Sjælland, Denmark. Bee bread with fungal growth resembling a spore cyst fungus was removed and the fungi isolated.

\section{Isolation and cultivation}

Isolates obtained for sequencing in this study were grown at $18{ }^{\circ} \mathrm{C}$ on a solid medium of malt agar with $20 \%$ dextrose (MY20). Spore cysts of Bettsia alvei and the asci of Eremascus fertilis were plated directly onto MY20 and kept at $18{ }^{\circ} \mathrm{C}$. Once sufficient growth was present to verify the identity of the fungus, a single hyphal tip was cut from each culture and transferred to a fresh plate. Specimens are deposited in the herbarium of The Natural History Museum of Denmark (C), and isolate cultures, given the designation "KVL \#\#-\#\#" (Table 1) are the part of the permanent fungal isolate collection of the Insect Pathology laboratory in the Department of Plant and Environmental Sciences at the University of Copenhagen (formerly Den Kongelige Veterinær og Landbohøjskole, or KVL), where they are stored at $-80{ }^{\circ} \mathrm{C}$.

\section{Molecular study}

For two strains of Eremascus fertilis and two strains of Bettsia alvei (Table 1), genomic DNA was obtained by picking up ascocarps and mycelium from isolate cultures and grinding them inside a $1.5 \mathrm{ml}$ Eppendorf tube. DNA was then isolated using the Qiagen DNeasy Plant Mini Kit (Hilden, Germany) using the standard protocol and eluted in two separate $50 \mu \mathrm{l}$ fractions to avoid overdilution.

The LSU and SSU regions were each amplified by PCR. Primers LROR and LR7 [37] were used to amplify $1.4 \mathrm{~kb}$ of LSU, and primers NS1 and NS4 [38] were used to amplify $1.1 \mathrm{~kb}$ of SSU. PCR reactions were prepared in $50 \mu \mathrm{l}$ volumes containing $29.8 \mu \mathrm{l}$ of sterile deionized water, $5 \mu \mathrm{l}$ of Taq polymerase reaction buffer $\left(\right.$ Sigma $\left.^{\circ}\right)$, $1.0 \mu \mathrm{l} 10 \mathrm{mM}$ dNTP, $3.0 \mu \mathrm{l} 25 \mathrm{mM} \mathrm{MgCl}, 0.2 \mu \mathrm{l} \mathrm{Taq}$ DNA polymerase $\left(\right.$ Sigma $\left.^{\circ}\right), 5.0 \mu \mathrm{l}$ each $10 \mu \mathrm{M}$ primer and $1 \mu \mathrm{l}$ of genomic DNA template. PCR was performed on a Biometra thermocycler (Whatman) under the following conditions: for LSU: step 1) $1 \mathrm{~min}$ at $95^{\circ} \mathrm{C}, 2$ ) $1 \mathrm{~min}$ at $94{ }^{\circ} \mathrm{C}$, 3) $30 \mathrm{sec}$ at $\left.51{ }^{\circ} \mathrm{C}, 4\right) 1 \mathrm{~min}$ at $72{ }^{\circ} \mathrm{C}, 5$ ) return to step 234 times, 6) final step of $10 \mathrm{~min}$ at $72{ }^{\circ} \mathrm{C}$; and for SSU: step 1) $1 \mathrm{~min}$ at $95{ }^{\circ} \mathrm{C}$, 2) $1 \mathrm{~min}$ at $94{ }^{\circ} \mathrm{C}, 3$ ) $30 \mathrm{sec}$ at $51^{\circ} \mathrm{C}$, 4) $1 \mathrm{~min}$ at $72{ }^{\circ} \mathrm{C}$, 5) $1 \mathrm{~min}$ at $94{ }^{\circ} \mathrm{C}, 6$ ) $30 \mathrm{sec}$ at $\left.53{ }^{\circ} \mathrm{C}, 7\right) 65 \mathrm{sec}$ at $\left.72{ }^{\circ} \mathrm{C}, 8\right)$ return to step 234 times, 9) final step of $10 \mathrm{~min}$ at $72{ }^{\circ} \mathrm{C}$. Samples were kept at $4{ }^{\circ} \mathrm{C}$ until electrophoresis was performed on $1 \%$ agarose TAE gels and visualized with EZvision $\mathrm{One}^{\circ}$ (Amresco). PCR products were cleaned using the Qiaquick $^{\odot}$ PCR purification kit (Qiagen) and were sent to Eurofins MWG Operon AG (Ebersberg, Germany) for sequencing. In addition to the amplification primers, LSU was sequenced with primers LR3R and LR5 [37], and SSU with primers NS2 [38] and SR7R (http:// sites.biology.duke.edu/fungi/mycolab/primers.htm). Sequences were assembled using BioEdit [39]. 
Table 1 Collection information for new isolates of Bettsia alvei and Skoua fertilis

\begin{tabular}{lllll}
\hline Taxon & Collection \# & Isolate \# & Habitat \& substrate & Locality \\
\hline B. alvei & 5158 & KVL 14-120 & honey bee comb; bee bread & Frederiksværk, DK \\
B. alvei & 5065 & KVL 14-119 & brood cell of Osmia bicornis; pollen & Taastrup, DK \\
S. fertilis & 5160 & KVL 10-10 & honey bee comb; bee bread & Hundested, DK \\
S. fertilis & 5159 & KVL 10-09 & honey bee comb; bee bread & Frederiksværk, DK \\
\hline
\end{tabular}

For each region, a data matrix that included sequences from two isolates of Eremascus fertilis, two isolates of Bettsia alvei, and 63 other ascomycetes (Table 2) was assembled and manually aligned in MEGA5 [40]. Taxon sampling was focused on genera with reduced fruiting bodies. Many of the sequences came from James et al. [8] and were downloaded from the AFToL website (aftol.org), while those from other studies [4, 41] came from GenBank. The LSU and SSU datasets were exported in NEXUS format and were combined in a single data file in PAUP* v. 4.0.10b [42]. The combined file was deposited in the Dryad Digital Repository, and can be accessed at http://dx.doi.org/10.5061/dryad.6s80j. This file was analyzed by maximum parsimony in PAUP*: using a random addition sequence and TBR swapping, 1000 heuristic replicates were performed, saving no more than ten best trees per replicate, followed by a final search of the saved trees. The file was also bootstrapped (2000 replicates) using the same search parameters except that only 10 heuristic replicates were performed per bootstrap replicate. A Bayesian analysis of the combined file was also performed using the program MrBayes v. 3.2 [43]. Based on the Akaike Information Criterion, the GTR $+\mathrm{I}+\Gamma$ model of DNA sequence evolution was selected as the best-fit model using the program Modeltest v. 3.06 [44]. A Markov chain Monte Carlo (MCMC) analysis was then run for 2,000,000 generations under the default settings, which was twice the number needed to keep the standard deviation of split frequencies below 0.01. Following Schoch et al. [4], Saccharomycotina was used as the outgroup for Pezizomycotina. Published single and multigene phylogenies $[24,45,4]$ were followed in naming the major clades shown in Fig. 3.

\section{Results}

\section{Collection}

The predominant bee species in the solitary bee nests were Osmia bicornis, O. leaiana and Megachile centuncularis and M. versicolor. Details of the contents of individual cells were recorded for 1553 of the approximately 8000 brood cells observed. Of 1553 brood cells, 1429 contained cocoons, 80 contained uneaten pollen provisions, and 182 had spore cysts on the pollen provisions, brood cell building materials, larval feces, larvae, or on the cocoon surface. Eighteen brood cells contained chalkbrood caused by Ascosphaera. Thirty-five of the 80 brood cells containing uneaten pollen provisions had Bettsia and Ascosphaera growing on and between the pollen grains. Bettsia and Eremascus were found growing on the beebread of honey bee frames from two different localities (Table 1).

\section{Phylogenetic relationships of Eremascus and Bettsia Molecular study}

The LSU matrix used for analysis included 862 characters, and the SSU matrix 1691 characters; the combined file thus included 2553 characters, of which 1762 were constant, 191 were variable but not parsimonyinformative, and 600 were parsimony-informative. Two equally most-parsimonious trees of 3716 steps were recovered: a phylogram of one of these trees is shown in Fig. 3. Topologically, the parsimony and Bayesian trees [see Additional file 1] were similar to those of previous studies $[8,4]$ based on more regions. The analysis of the combined dataset placed Eremascus fertilis in a wellsupported clade (bootstrap [BS] $=87$; posterior probability $[\mathrm{PP}]=1$ ) with Byssoascus striatosporus (G.L. Barron \& C. Booth) Arx and Myxotrichum deflexum Berk. Eremascus albus, the type species of the genus, was resolved in Eurotiomycetes, sister to Ascosphaera $(\mathrm{BS}=82, \mathrm{PP}=1)$. Bettsia belonged to a fully supported clade including the leotiomycete genera Pseudogymnoascus, Leuconeurospora and Pseudeurotium. Although the Leotiomycetes clade did not receive statistical support, the Eurotiomycetes clade was well supported $(\mathrm{BS}=95, \mathrm{PP}=1)$.

Eremascus is a polyphyletic taxon. A new genus is needed for E. fertilis which is evidently related to Myxotrichum and Byssoascus. The placement of E. fertilis with Myxotrichaceae is supported morphologically by its narrow ellipsoid ascospores and uncoiled suspensors resembling stipitate asci (Fig. 2b-c). Narrow ascospores and stipitate asci are characteristic of Myxotrichaceae but are anomalous in the Onygenales (Eurotiomycetes), where E. fertilis was formerly placed [46].

The placement of Bettsia alvei in Leotiomycetes (Fig. 3) agrees with recent studies [21, 22]. Thus, Ascosphaeraceae as traditionally understood is also polyphyletic and the family must be circumscribed more narrowly to include Ascosphaera and Arrhenosphaera, but not Bettsia. Bettsia is most closely related to Pseudeurotium, Pseudogymnoascus and Leuconeurospora in the family Pseudeurotiaceae. The cleistothecium of Pseudeurotium is formed by a 
Table 2 Isolates and/or voucher specimens and GenBank accession numbers for LSU and SSU sequences

\begin{tabular}{|c|c|c|c|}
\hline \multirow[t]{2}{*}{ Taxon } & \multirow[t]{2}{*}{ Isolate/strain/voucher specimen } & \multicolumn{2}{|c|}{ GenBank ID/Sequence source } \\
\hline & & LSU rDNA & SSU rDNA \\
\hline Acarospora schleicheri & VR 5-VII-98/30 & AY640945 & AY640986 \\
\hline Aleuria aurantia & OSC 100018 & AY544654 & NG_013139 \\
\hline Anisomeridium polypori & $4237 a$ & DQ782906 & DQ782877 \\
\hline Ascosphaera apis & CBS 402.96 & FJ358275.1 & FJ358343 \\
\hline Ascosphaera larvis & ARSEF 7946 & $J \times 268535$ & $J \times 268535$ \\
\hline Aspergillus fumigatus & ATCC 1022/JCM1738 & AY660917 & AB008401 \\
\hline Aspergillus nidulans & ATCC 16855/ FGSC4 & AF454167 & U77377 \\
\hline Bettsia alvei & AA Wynns 5065 (C) & KR139932 & KR139928 \\
\hline Bettsia alvei & AA Wynns 5158 (C) & KR139933 & KR139929 \\
\hline Botryotinia fuckeliana & OSC 100012 & AY544651 & AY544695 \\
\hline Byssoascus striatisporus & CBS 642.66 & AB040688 & AJ315170 \\
\hline Byssochlamys nivea & CBS 100.11 & FJ358279 & FJ358345 \\
\hline Caloscypha fulgens & OSC 100062 & DQ247799 & DQ247807 \\
\hline Candida albicans & SC5314 & AACQ01000290 & AACQ01000290 \\
\hline Candida tropicalis & MUCL30002 & AAFN01000124 & M55527 \\
\hline Capnodium coffeae & CBS147.52 & DQ247800 & DQ247808 \\
\hline Capronia pilosella & W. Untereiner WUC28 & DQ823099 & DQ823106 \\
\hline Chlorociboria aeruginosa & OSC 100056 & AY544669 & AY544713 \\
\hline Cladonia caroliniana & F. M. Lutzoni 01-26-03.2 & AY584640 & AY584664 \\
\hline Coccidioides immitis & ATCC 28868 & AAEC0200 & AAEC0200 \\
\hline Coccomyces dentatus & OSC 100021 & AY544657 & AY544701 \\
\hline Cochliobolus heterostrophus & CBS 134.39 & AY544645 & AY544727 \\
\hline Cudoniella clavus & OSC 100054 & DQ470944 & DQ470992 \\
\hline Dactylella oxyspora & CBS 280.70 & AY902790 & AY902797 \\
\hline Dermea acerina & CBS 161.38 & DQ247801 & DQ247809 \\
\hline Diaporthe eres & CBS 109767 & AF408350 & DQ471015 \\
\hline Dothidea sambuci & DAOM 231303 & AY544681 & AY544722 \\
\hline Eleutherascus lectardii & CBS 626.71 & DQ168334 & DQ062997 \\
\hline Endocarpon cf. pusillum & S. Joneson 4028 & DQ823097 & DQ823104 \\
\hline Eremascus albus & UCB 50-026 & M83258 & GQ867787 \\
\hline Eremascus albus & CBS 975.69 & FJ358283.1 & FJ358348.1 \\
\hline Eremascus (Skoua) fertilis & AA Wynns 5159 (C) & KR139934 & KR139931 \\
\hline Eremascus (Skoua) fertilis & AA Wynns 5160 (C) & HQ540515 & KR139930 \\
\hline Exophiala pisciphila & W. Untereiner WUC 137 & DQ823101 & DQ823108 \\
\hline Geoglossum nigritum & OSC 100009 & AY544650 & AY544694 \\
\hline Gymnoascus reesii & CBS 259.61 & FJ358284 & FJ358349 \\
\hline Gyromitra californica & OSC 100068 & AY544673 & AY544717 \\
\hline Histoplasma capsulatum & AFTOL 1083 & James et al. 2006 [8] & James et al. 2006 [8] \\
\hline Hydropisphaera erubescens & ATCC 36093 & AY545726 & AY545722 \\
\hline
\end{tabular}

cellular peridium [47] rather than a double membrane as in a spore cyst, and the ascomal ontogeny of Pseudeurotium [48] is markedly different from that of a spore cyst $[49,50]$. However, Pseudeurotium and Bettsia are similar in that they both have prototunicate asci and globose ascospores. 


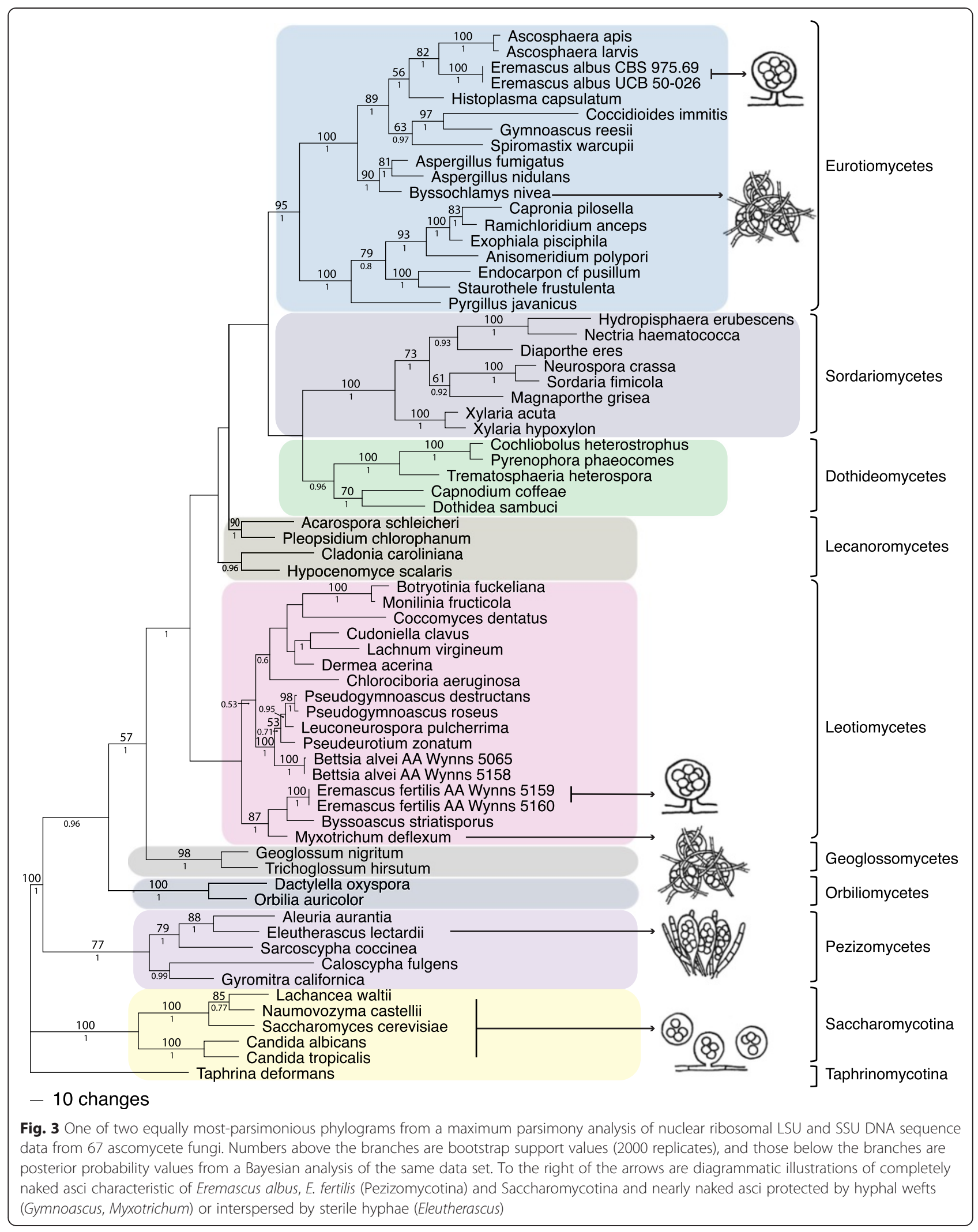




\section{Taxonomy}

Skoua A.A. Wynns, gen. nov.

Index Fungorum: IF551198

Type. Skoua fertilis (Stoppel) A.A. Wynns

Description Ascomata absent. Asci borne laterally from undifferentiated hyphae, prototunicate, subglobose, stipitate-like from two suspensors. Ascospores ellipsoid, smooth, hyaline.

Etymology The generic name Skoua commemorates the Danish bee pathologist J. P. Skou, in acknowledgement of his major contribution to our understanding of spore cyst fungi.

Skoua fertilis (Stoppel) A.A. Wynns, comb. nov. Fig. $2 \mathrm{a}-\mathrm{e}$

Index Fungorum: IF551199

Basionym. Eremascus fertilis Stoppel, Flora 97: 332. 1907.

Neotype of Eremascus fertilis (here designated): DENMARK: Zealand, Frederiksværk. Isolated from overwintering bee bread of Apis mellifera hive 74 belonging to Christian Pedersen, collected by A.A. Wynns 5159 (C). Index Fungorum: IF551197

Description Naked asci subglobose, 9-12 $\mu \mathrm{m}$, on average $11 \mu \mathrm{m}$. Ascospores $4-8 \times 3-5 \mu \mathrm{m}$. Natural habitat on beebread inside the nests of Apis mellifera. In vitro growth at $18{ }^{\circ} \mathrm{C}$, a low white mycelium on MY20, pale buff and radially sulcate with age (Fig. 2a), with abundant asci after four weeks. Conidia not observed.

Notes-In his description of E. fertilis, Stoppel [34] did not explicitly designate a holotype for this species; therefore, the ex-culture specimen A.A. Wynns 5159 deposited in herbarium $C$ is here designated as the neotype.

\section{Discussion}

\section{Convergent evolution of reduced fruiting bodies}

Peridia, or the protective structures enclosing asci and ascospores, are diverse among the cleistothecial fungi. Peridia range from completely closed structures composed of many cells (e.g., Pseudeurotium), to cottony or cage-like enclosures of hyphae (e.g., Byssochlamys, Myxotrichum, Gymnoascus), to simple hyphae interspersed among naked asci and not forming an enclosure (e.g., Byssoascus). The morphology of the peridium was once thought to indicate relatedness [51] but hyphal or meshlike peridia, cephalothecoid peridia, and now membranous peridia are known to have independently evolved in unrelated lineages and in taxa associated with insects $[4,5]$.

The results of the phylogenetic analyses (Fig. 3) unambiguously show that Eremascus fertilis is excluded from the class Eurotiomycetes and is not closely related to the type species of the genus, E. albus. Eremascus fertilis is therefore transferred to the new genus Skoua. This genus is closest to Myxotrichacaeae, a family formerly placed in Eurotiomycetes but now considered to be a member of Leotiomycetes based on nrDNA-based phylogenies $[45,52]$. Derived naked asci thus evolved at least twice within the Pezizomycotina: once in Eremascus (Eurotiomycetes) and once in Skoua (Leotiomycetes). Completely naked asci (i.e.,without any vestigial peridial hyphae) occur elsewhere only in the basal lineages of Ascomycota (Taphrinomycotina and Saccharomycotina) [53]. Unlike the yeasts and yeast-like filamentous fungi (e.g. Symbiotaphrina, Aureobasidium), asexual reproduction by budding, fission, or otherwise does not occur in Eremascus and Skoua; therefore, the only yeast-like character of Skoua and Eremascus is naked asci.

Several taxa in Pezizomycotina (e.g., Byssochlamys, Gymnoascus, Pseudogymnoascus, Myxotrichum, Eleutherascus, Ascodesmis) produce nearly naked asci that are enclosed by or interspersed with a loose network of hyphae (Fig. 3) known as a telaperidium or a reticuloperidium. Telaperidial and reticuloperidial ascomata are interpreted as loosely arranged cleistothecia or apothecia, a derived condition [46]. Interestingly, Eremascus albus and Skoua fertilis are allied to telaperidial and reticuloperidial taxa in both Eurotiomycetes (e.g., Byssochlamys, Gymnoascus) and Leotiomycetes (e.g., Myxotrichum, Byssoascus) (Fig. 3). More sequence data are needed to determine if the naked ascus in $S$. fertilis evolved by reduction from a reticuloperidium or if reticuloperidial taxa evolved from Skoua-like ancestors. Reduced fruiting bodies are also found in Ascodesmis and Eleutherascus in Pezizomycetes, the most basal clade of the Pezizomycotina. In Ascodesmis the fruiting body consists of a bundle of naked asci.

\section{Morphological convergence and dispersal}

The discovery that the spore cyst and the naked ascus have each evolved twice in unrelated lineages of beeassociated fungi suggests that these reduced fruiting bodies are well adapted to the bee habitat. Convergent evolution of fruiting body types and ascus types in unrelated fungi with similar dispersal strategies has occurred repeatedly in the Pezizomycotina, e.g., ascomata with reticuloperidial or cephalothecoid peridia [5, 54-56]. Evanescent asci or asci which break down to release the ascospores passively evolved mutiple times in the Ascomycota and are correlated with insect dispersal [4, 57]. Similarly, the fragile peridium of the spore cyst fungi Ascosphaera and Bettsia and the evanescent naked asci of Skoua and Eremascus are interpreted as adaptive for dispersal by bees. Spore cysts break down when touched and dehisce with the activity of the bees, for example as bees move over and chew through the contents of brood cells in the process of emergence from their natal nests 
and during routine maintenance and construction of brood cells $[58,25,59]$. Disrupting the spore cyst membrane and subsequently picking up spores during emergence is a major contributor to the spread of chalkbrood in the managed solitary bee Megachile rotundata [60]. As the spore cysts are broken open, a sticky mucilage on the ascospores of Bettsia and Ascosphaera further ensures dispersal by the bee host $[58,25]$.

Spore cysts are not just broken open by the activity of bees, they also become impaled on their setae (Fig. 4). Impalement of fruiting bodies on arthropod setae is a spore dispersal mechanism found in other fungi, e.g. Myxotrichum (Leotiomycetes) and Auxarthron (Eurotiomycetes) [5]. In Myxotrichum and Auxarthron the mesh-like hyphal peridia function in attachment to the arthropod setae. Once impaled, ascospores fall through the holes in the mesh-like peridium and are dispersed as the insect (e.g., a fly) moves or flies around [5].

In this study, the peridia or membranous spore cyst walls of Ascosphaera and Bettsia growing within the nests of solitary bees remained intact in overwintering bee nests and in the absence of nesting activity. This is reminiscent of the spore dispersal strategy of Myxomycetes

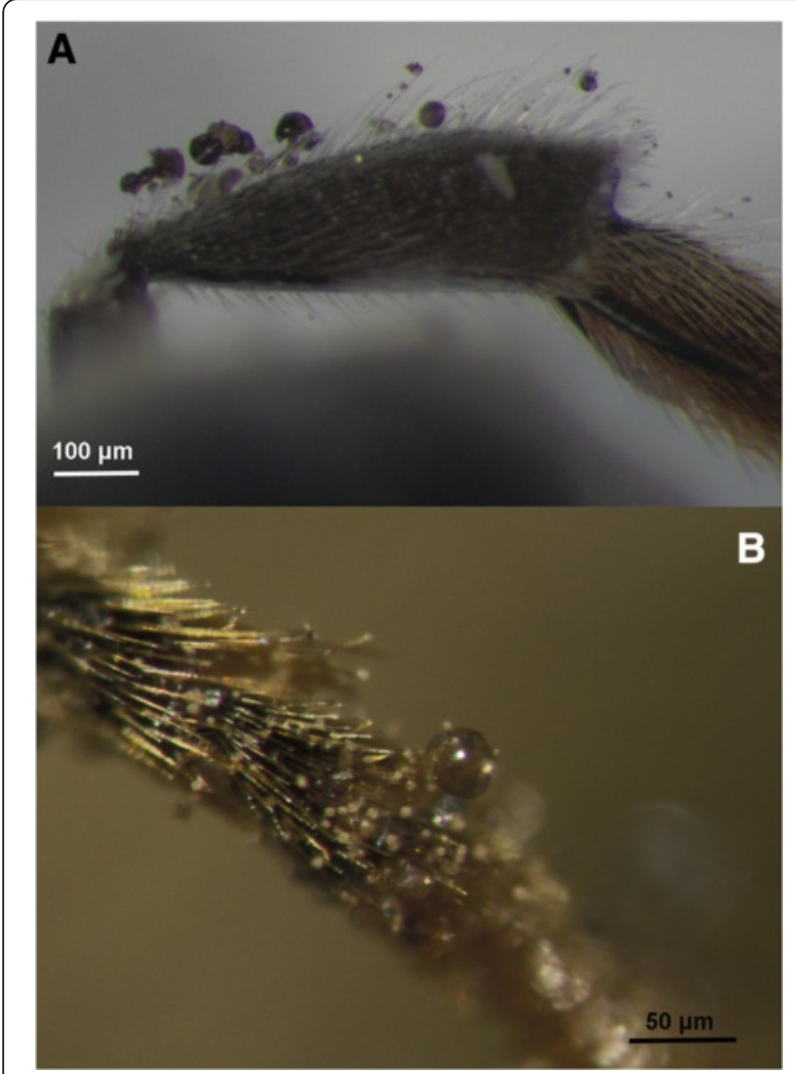

Fig. 4 a-b Hind tibia of the solitary bee Osmia bicornis showing impaled spore cysts and sporeballs attached to hairs after contact with Ascosphaera atra. Scale bars: $\mathbf{a}=100 \mu \mathrm{m}, \mathbf{b}=50 \mu \mathrm{m}$ living in sheltered habitats. The peridium of Myxomycetes is dependent on the movement of invertebrates to disrupt the membrane, while in the absence of invertebrates the peridium remains intact for months [61].

The diversity and abundance of the spore cyst fungi is greater in the nests of solitary bees than in eusocial bees. The combination of the lack of social grooming and the nesting habits of solitary bees may contribute to the diversity and abundance of spore cyst fungi within the nests of these bees. In contrast to eusocial bees (e.g., honey bees), which may be active for months, solitary bees in temperate regions usually have only one generation per year and a relatively brief nesting and active period, sometimes as short as three weeks [62]. These nesting habits provide a stable environment for the slow-growing spore cyst fungi to establish and to develop mature ascocarps. On the other hand, because the active period of solitary bees is short compared with their eusocial relatives, the period for successful ascospore dispersal is much reduced. Ascospore release, coupled with the activity of the bees, maximizes spore dispersal of the fungus specifically by its host. Ensuring that ascospore release occurs in conjunction with the activity of the bees is particularly adaptive in the solitary bee habitat where the linear arrangement of brood cells means that siblings must pass through other brood cells to emerge from the nest (Fig. 1c-d).

Bee-mediated dispersal may be particularly critical for the spore cyst fungi and for Eremascus and Skoua because of their physiological requirements as xerophiles. Eremascus and Bettsia are included among the few xerophilic fungi called extreme xerophiles, meaning that they require rather than prefer a substrate with low water activity [63]. The bee habitat is a temporally static micro-environment that provides low water activity substrates, e.g., honey, bee bread, and pollen provisions, on which these slow growing xerophiles are able to thrive. A habitat with the combination of a temporally static environment and a provision of low water activity substrates is undoubtedly uncommon in nature and possibly unique to the nests of bees.

\section{Conclusions}

Microbial symbionts in bee nests and within the bees themselves may play a major role in maintaining bee health and in disease defense [64-67]. However, characterization of the microbial community in even the best-studied bee system, the honey bee, remains understudied, and its beneficial potential poorly understood [65]. Even less is known about the fungi intimately associated with the many species of solitary bees that make up the majority of the 20,000 bee species [68]; the literature is sparse [69] and the subject almost entirely unexplored. Understanding the phylogenetic 
relationships of resident fungi within bee nests and their dispersal strategies may help to elucidate the role of these organisms in the bee habitat.

In this study, the systematic relationships of the bee specialist fungi are clarified and the monotypic genus Skoua is added to the microbial community associated with bees. The convergent evolution of spore cysts in Bettsia and Ascosphaera, and of naked asci in Eremascus and Skoua, is proposed to be adaptive for spore dispersal in the bee habitat. A taxonomic framework is provided for future studies of the understudied fungi occurring in this highly specialized niche.

\section{Availability of supporting data}

The data set supporting the results of this article is available in the Dryad Digital repository; doi:10.5061/ dryad.6s80j, http://dx.doi.org/10.5061/dryad.6s80j.

\section{Additional file}

\section{Additional file 1: A supplementary figure in PDF format (.pdf).}

$50 \%$-majority rule consensus phylogram from a Bayesian analysis of nuclear ribosomal LSU and SSU DNA sequence data from 67 ascomycete fungi.

\section{Competing interests}

The author declares that they have no competing interests.

\section{Acknowledgments}

Funding for the project was provided by the University of Copenhagen and the Danish National Research Foundation.

Received: 24 October 2014 Accepted: 1 June 2015

Published online: 21 July 2015

\section{References}

1. Pöggeler S, Nowrousian M, Kück U. Fruiting-body development in ascomycetes. In: Ka F, editor. The Mycota. Berlin: Springer; 2006. p. 325-55.

2. Kirk PM, Cannon PF, Minter DW, Stalpers JA. Dictionary of Fungi. 10th ed. Wallingford: CAB International; 2008.

3. Berbee ML, Taylor JW. Two ascomycete classes based on fruiting-body characters and ribosomal DNA sequences. Mol Biol Evol. 1992;9(2):278-84.

4. Schoch CL, Sung GH, Lopez-Giraldez F, Townsend JP, Miadlikowska J, Hofstetter $V$, et al. The Ascomycota tree of life: a phylum-wide phylogeny clarifies the origin and evolution of fundamental reproductive and ecological traits. Syst Biol. 2009;58(2):224-39. doi:10.1093/sysbio/syp020.

5. Greif MD, Currah RS. A functional interpretation of the role of the reticuloperidium in whole-ascoma dispersal by arthropods. Mycol Res. 2003;107:77-81. doi:10.1017/S0953756202007104.

6. Lutzoni F, Kauff F, Cox CJ, McLaughlin D, Celio G, Dentinger B, et al. Assembling the fungal tree of life: progress, classification and evolution of subcellular traits. Am J Bot. 2004;91(10):1446-80. doi:10.3732/ajb.91.10.1446.

7. Liu YJ, Hall BD. Body plan evolution of ascomycetes, as inferred from an RNA polymerase II phylogeny. Proc Natl Acad Sci U S A. 2004;101(13):4507-12. doi:10.1073/pnas.0400938101.

8. James TY, Kauff F, Schoch CL, Matheny PB, Hofstetter V, Cox CJ, et al. Reconstructing the early evolution of Fungi using a six-gene phylogeny. Nature. 2006;443(7113):818-22. doi:10.1038/Nature05110.

9. Stejskal M. Arrhenosphaera cranei gen. et sp. nov., a beehive fungus found in Venezuela. J Apicult Res. 1974;13:39-45.

10. Anderson DL, Gibson NL. New species and isolates of spore-cyst fungi (Plectomycetes: Ascosphaerales) from Australia. Aust Syst Bot. 1998;11:53-722.

11. Bissett J. Contribution toward a monograph of the genus Ascosphaera. Can J Bot. 1988;66(12):2541-60
12. Youssef NN, McManus WR. Ascosphaera torchioi sp. nov., a pathogen of Osmia lignaria propinqua Cresson (Hymenoptera). Mycotaxon. 2001;77:7-13.

13. Wynns AA, Jensen AB, Eilenberg J. Ascosphaera callicarpa, a new species of bee-loving fungus, with a key to the genus for Europe. PloS one. 2013;8(9). doi:10.1371/journal.pone.0073419.

14. Wynns AA, Jensen AB, Eilenberg J, James R. Ascosphaera subglobosa, a new spore cyst fungus from North America associated with the solitary bee Megachile rotundata. Mycologia. 2012;104(1):108-14. doi:10.3852/10-047.

15. Betts AD. A bee-hive fungus, Pericystis alvei, gen. et sp. nov. Ann Bot-London. 1912;26(101-4):795-9.

16. Geiser D, LoBuglio K. The monophyletic Plectomycetes: Ascosphaerales, Onygenales, Eurotiales. In: McLaughlin D, McLaughlin E, Lemke P, editors The Mycota: systematics and evolution. Berlin: Springer; 2001. p. 201-20.

17. Spiltoir CF, Olive LS. A reclassification of the genus Pericystis Betts. Mycologia. 1955;47(2):238-44. doi:10.2307/3755414.

18. Malloch DW, Mouchacca J. Ascosphaerales, Elaphomycetales, Erysiphales, Eurotiales, Glaziellales, Laboulbeniales, Microascales, Onygenales, Spathulosporales. In: Hawksworth DL, editor. Ascomycete systematics: problems and perspectives in the nineties. NATO ASI Series A, vol. 269. New York: Plenum Press; 1994. p. 365-70.

19. Bessey EA. Morphology and taxonomy of Fungi. New York: Hafner Press; 1950.

20. Skou JP. Ascosphaerales and their unique ascomata. Mycotaxon. 1982;15(1):487-99.

21. Pitt Jl, Lantz H, Pettersson OV, Leong SL. Xerochrysium gen. nov. and Bettsia, genera encompassing xerophilic species of Chrysosporium. IMA fungus. 2013;4(2):229-41. doi:10.5598/imafungus.2013.04.02.08.

22. Wynns A. The bee specialist fungus family Ascosphaeraceae and its allies: systematics, ecology and co-evolution with solitary bees [Dissertation] University of Copenhagen, Copenhagen, Denmark; 2012.

23. Berbee ML, Yoshimura A, Sugiyama J, Taylor JW. Is Penicillium monophyletic? An evaluation of phylogeny in the family Trichocomaceae from 18S, 5.85 and ITS ribosomal DNA sequence data. Mycologia. 1995;87(2):210-22. doi:10.2307/3760907.

24. Geiser DM, Gueidan C, Miadlikowska J, Lutzoni F, Kauff F, Hofstetter V, et al. Eurotiomycetes: Eurotiomycetidae and Chaetothyriomycetidae. Mycologia. 2006;98(6):1053-64.

25. Skou JP. Ascosphaerales. Friesia. 1972;10:1-24.

26. Berbee ML, Taylor JW. Detecting morphological convergence in true fungi, using 18S rRNA gene sequence data. Biosystems. 1992;28(1-3):117-25. doi:10.1016/0303-2647(92)90014-P.

27. Kregerva NJ, Veenhuis M, Leemburg CA. Ultrastructure of hyphae and ascospores in genus Eremascus Eidam. A Van Leeuw J Microb. 1974;40(4):533-42. doi:10.1007/Bf00403817

28. Pitt J, Hocking A. Xerophiles. In: Pitt J, Hocking A, editors. Fungi and Food Spoilage. 3rd ed. US: Springer; 2009. p. 339-55.

29. Blackwell M, Kurtzman CP, Lachance M-A, Suh S-O. Saccharomycotina. Saccharomycetales. In: The Tree of Life Web Project. 2009. http://tolweb.org/ Saccharomycetales/29043/2009.01.22 2014. Accessed 1 Oct 2014

30. Stelling-Dekker NM. Die sporogenen Hefen [Dissertation]. Amsterdam: Utrecht University; 1931

31. Stchigel AM, Guarro J. A reassessment of cleistothecia as a taxonomic character. Mycol Res. 2007;111:1100-15. doi:10.1016/j.mycres.2007.02.008.

32. Sigler L, Hambleton S, Pare JA. Chlamydosauromyces punctatus gen. \& sp. nov. (Onygenaceae) from the skin of a lizard. Stud Mycol. 2002;47:123-9.

33. Stoppel R. Eremascus fertilis, nov. spec. Flora. 1907;97:332-46.

34. Harrold CE. Studies in the genus Eremascus I. The rediscovery of Eremascus albus Eidam and some new observations concerning its life-history and cytology. Ann Bot-London. 1950;14(54):127-48

35. Betts AD. The fungi of the bee-hive. The Journal of Economic Botany. 1912;7:129-62

36. Thiers, B. [continuously updated]. Index Herbariorum: A global directory of public herbaria and associated staff. New York Botanical Garden's Virtual Herbarium. http://sweetgum.nybg.org/ih/ Accessed 1 Jan 2015

37. Vilgalys R, Hester M. Rapid Genetic identification and mapping of enzymatically amplified ribosomal DNA from several Cryptococcus species. J Bacteriol. 1990;172(8):4238-46.

38. White TJ, Bruns T, Lee S, Taylor J. Amplification and direct sequencing of fungal ribosomal RNA genes for phylogenetics. In: Innis MA, Gelfand DH, Sninksy JJ, White TJ, editors. PCR protocols: a guide to methods and applications. San Diego: Academic; 1990. p. 315-22. 
39. Hall TA. BioEdit: a user-friendly biological sequence alignment editor and analysis program for Windows 95/98/NT. Nucleic Acids Symp Ser. 1999;41:95-8.

40. Tamura K, Peterson D, Peterson N, Stetcher G, Nei M, Kumar S. MEGA5: Molecular Evolutionary Genetics Analysis using maximum likelihood, evolutionary distance, and maximum parsimony methods. Mol Biol Evol. 2011;28:2731-9.

41. Lumbsch HT, Schmitt I, Lindemuth R, Miller A, Mangold A, Fernandez F, et al. Performance of four ribosomal DNA regions to infer higher-level phylogenetic relationships of inoperculate euascomycetes (Leotiomyceta). Mol Phylogenet Evol. 2005;34(3):512-24. doi:d0.1016/j.ympev.2004.11.007.

42. Swofford DL. PAUP*: phylogenetic analysis using parsimony $\left(^{*}\right.$ and other methods). 4.0.b10 ed. Sunderland: Sinauer Associates; 2002.

43. Ronquist F, Teslenko M, van der Mark P, Ayres DL, Darling A, Hohna S, et al. MrBayes 3.2: efficient Bayesian phylogenetic inference and model choice across a large model space. Syst Biol. 2012;61(3):539-42. doi:10.1093/sysbio/ sys029.

44. Posada D, Crandall KA. MODELTEST: testing the model of DNA substitution Bioinformatics. 1998;14(9):817-8.

45. Wang Z, Johnston PR, Takamatsu S, Spatafora JW, Hibbett DS. Toward a phylogenetic classification of the Leotiomycetes based on rDNA data. Mycologia. 2006;98(6):1065-75. doi:10.3852/mycologia.98.6.1065.

46. Tsuneda A, Currah RS. Ascomatal morphogenesis in Myxotrichum arcticum supports the derivation of the Myxotrichaceae from a discomycetous ancestor. Mycologia. 2004;96(3):627-35. doi:10.2307/3762179.

47. Hanlin RT. Combined keys to illustrated genera of ascomycetes, vol. 2. St. Paul: APS Press; 1998.

48. Stolk AC. The genera Anixiopsis Hansen and Pseudeurotium Van Beyma. Antonie Van Leeuwenhoek. 1955;21(1):65-79.

49. Spiltoir CF. Life cycle of Ascosphaera apis (Pericystis apis). Am J Bot. 1955:42(6):501-8. doi:10.2307/2438686.

50. Kish LP, Bowers NA, Benny GL, Kimbrough JW. Cytological development of Ascosphaera atra. Mycologia. 1988;80(3):312-9. doi:10.2307/3807627.

51. Currah RS. Taxonomy of the Onygenales: Arthrodermataceae, Gymnoascaceae, Myxotrichaceae and Onygenaceae. Mycotaxon. 1985;24:1-216.

52. Wang Z, Binder M, Schoch CL, Johnston PR, Spatafora JW, Hibbett DS. Evolution of helotialean fungi (Leotiomycetes, Pezizomycotina): a nuclear rDNA phylogeny. Mol Phylogenet Evol. 2006;41(2):295-312. doi:10.1016/ j.ympev.2006.05.031.

53. Rodriguez RJ, Cullen D, Kurtzman CP, Khchatourians GG, Hegedus DD 6 - Molecular methods for discriminating taxa, monitoring species, and assessing fungal diversity. In: Foster GMMFBS, editor. Biodiversity of Fungi. Burlington: Academic; 2004. p. 77-102.

54. Greif MD, Stchigel AM, Miller AN, Huhndorf SM. A re-evaluation of genus Chaetomidium based on molecular and morphological characters. Mycologia. 2009;101(4):554-64.

55. Greif MD, Currah RS. Development and dehiscence of the cephalothecoid peridium in Aporothielavia leptoderma shows it belongs in Chaetomidium. Mycol Res. 2007;111(1):70-7. doi:10.1016/j.mycres.2006.09.016.

56. Greif MD, Tsuneda A, Currah RS. The peridial development and dehiscence mechanism of Cryptendoxyla hypophloia, a cleistothecial ascomycete isolated from the bodies of arthropods. Int J Plant Sci. 2004;165(6):957-64. doi:10.1086/423873.

57. Berbee ML, Taylor JW. Convergence in ascospore discharge mechanism among pyrenomycete fungi based on $18 \mathrm{~S}$ ribosomal RNA gene sequence. Mol Phylogenet Evol. 1992;1(1):59-71. doi:10.1016/1055-7903(92)90036-G.

58. Holm SVN, Skou JP. Studies on trapping, nesting and rearing of some Megachile species (Hymenoptera, Megachilidae) and on their parasites in Denmark. Entomol Scand. 1972;3:169-80.

59. James RR. The problem of disease when domesticating bees. In: James R, Pitts-Singer TL, editors. Bee pollination in agricultural ecosystems. New York: Oxford University Press; 2008. p. 124-41.

60. Vandenberg JD, Fichter BL, Stephen WP. Spore load of Ascosphaera species on emerging adults of the alfalfa leafcutting bee, Megachile rotundata. Appl Environ Microbiol. 1980;39(3):650-5.

61. Blackwell M. Myxomycetes and their arthropod associates. In: Wheeler Q, Blackwell M, editors. Fungus-insect relationships. New York: Columbia University Press; 1983. p. 67-90.

62. Stephen WP, Bohart GE, Torchio PF. The biology and external morphology of bees. Corvallis: Oregon State University; 1969.
63. Pettersson OV, Leong SL. Fungal Xerophiles (Osmophiles). eLS. John Wiley \& Sons, Ltd; 2001. doi:10.1002/9780470015902.a0000376.pub2.

64. Gilliam M, Roubik DW, Lorenz BJ. Microorganisms associated with pollen, honey, and brood provisions in the nest of a stingless bee, Melipona fasciata. Apidologie. 1990;21(2):89-97. doi:10.1051/apido:19900201.

65. Anderson KE, Sheehan TH, Eckholm BJ, Mott BM, DeGrandi-Hoffman G. An emerging paradigm of colony health: microbial balance of the honey bee and hive (Apis mellifera). Insect Soc. 2011;58(4):431-44. doi:10.1007/s00040011-0194-6.

66. McFrederick QS, Mueller UG, James RR. Interactions between fungi and bacteria influence microbial community structure in the Megachile rotundata larval gut. P Roy Soc B-Biol Sci. 2014;28:1779. doi:10.1098/Rspb.2013.2653.

67. Gilliam M. Identification and roles of non-pathogenic microflora associated with honey bees. Fems Microbiol Lett. 1997;155:1-10.

68. Michener CD. Comparative social behavior of bees. Annu Rev Entomol 1969;14:299-342. doi:10.1146/annurev.en.14.010169.001503.

69. Rosa CA, Lachance MA, Silva JO, Teixeira AC, Marini MM, Antonini Y, et al. Yeast communities associated with stingless bees. FEMS Yeast Res. 2003;4(3):271-5.

\section{Submit your next manuscript to BioMed Central and take full advantage of:}

- Convenient online submission

- Thorough peer review

- No space constraints or color figure charges

- Immediate publication on acceptance

- Inclusion in PubMed, CAS, Scopus and Google Scholar

- Research which is freely available for redistribution 